\title{
BANDING STUDIES OF GIANT PETRELS, MACRONECTES SPP., AT MACQUARIE ISLAND
}

\author{
by E.J. Woehler and G.W. Johnstone
}

(with five tables and seven text--figures)

WOEHLER, E.J. \& JOHNSTONE, G.W., 1988 (viii): Banding studies of giant petrels, Macronecres spp., at Macquarie Island. Pap. Proc. R. Soc. Tasm., 122(1): 143-152. Papers presented at the Macquarie Island Symposium, Hobart, May 1987. https://doi.org/10.26749/rstpp.122.1.1.143 ISSN 0080-4703. Antarctic Division, Department of Science, Channel Highway, Kingston, Tasmania, Australia 7150.

Between 1 July 1967 and 3 June 1987, totals of giant petrels banded at Macquarie Island $\left(54^{\circ} 30^{\prime} \mathrm{S}, 158^{\circ} 57^{\prime} \mathrm{E}\right)$ were northern giant petrel (Macronectes halli) - 3056 chicks, 583 adults; southern giant petrel (Macronectes giganteus) -- 369 chicks, 47 adults.

Recoveries of known-age breeding birds of both species indicate age at first breeding to be six years. Birds banded as adults have been recovered breeding at ages of at least 24 years (northern) and at least 22 years (southern).

Recoveries, away from Macquarie Island, of northern giant petrels banded as chicks exhibit an eastward progression. Fifty-eight percent of recoveries were reported within 12 months of fledging and three birds were recovered in their ninth year.

Four giant petrels ( 2 northern, 1 southern and 1 unknown) banded elsewhere have been recovered at Macquarie Island. Key Words: giant petrel, bird banding studies, Macquarie Island.

\section{INTRODUCTION}

The northern giant petrel(Macronectes halli) and the southern giant petrel (Macronectes giganteus) breed sympatrically on Macquarie Island $\left(54^{\circ} 30^{\prime} \mathrm{S}, 158^{\circ} 57^{\prime} \mathrm{E}\right)$. The estimated breeding populations are approximately 1000 pairs of the northern giant petrel and 4000 pairs of the southern giant petrel (Johnstone 1977).

Prior to 1967, giant petrels were treated as a single, polymorphic species. However, Bourne \& Warham (1966) recognised two species, based on differences in breeding behaviour and morphology. The northern giant petrel breeds on islands north of the Antarctic Convergence and at South Georgia (south of the Antarctic Convergence). The southern giant petrel breeds on islands from just north of the Antarctic Convergence south to the Antarctic Continent. A narrow zone of overlap exists and there are at least four localities (Marion Island, Iles Crozet, Macquarie Island and South Georgia) where the two species are sympatric (Johnstone 1977, Hunter 1984a).

Breeding biology of the southern giant petrel has been reported by Mougin (1968), Conroy (1972) and Hunter (1984a). Warham (1962) reported breeding data from Macquarie Island prior to the separation of the two species. Johnstone (1977) and Hunter (1985) described feeding ecology for both species.
Downes et al. (1954), Howard (1956), Ingham (1959) and Sladen et al. (1968) reported early banding and recovery data from giant petrels banded at Macquarie Island and South Georgia. Tickell \& Scotland (1961) and Araya (1973) report more recent recovery data for southern giant petrels from Signy Island and Nelson Island respectively. Recovery data for known northern and southern giant petrels banded at South Georgia are reported by Hunter (1984b).

The aim of this paper is to report and analyse banding and recovery data for northern and southern giant petrels banded annually at Macquarie Island since the $1967-68$ breeding season.

\section{METHODS}

Banding of adults and chicks has been undertaken in most seasons at Macquarie Island since the 1954-55 breeding season. From 1 July 1954 to 30 June 1967, a total of 7319 chicks and 810 adults, of unknown specific status, were banded. Unless specifically recognised at the time (or location) of recovery, these birds have been excluded from the analysis and subsequent discussion, as most recoveries refer to birds of unknown species. In the period 1 July 1967 to 30 June 1986, a total of 3056 chicks and 583 adult 
TABLE 1

Banding of Giant Petrels at Macquarie Island, 1 July 1954 to 30 June 1986

\begin{tabular}{|c|c|c|c|c|c|c|}
\hline \multirow{2}{*}{ Season } & \multicolumn{2}{|c|}{ Macronectes spp. } & \multicolumn{2}{|c|}{ Macronectes halli } & \multicolumn{2}{|c|}{ Macronectes giganteus } \\
\hline & chicks & adults & chicks & adults & chicks & adults \\
\hline 195455 & 272 & 200 & & & & \\
\hline $1955 \quad 56$ & 1483 & 482 & & & & \\
\hline $1956-57$ & 824 & 59 & & & & \\
\hline $1957-58$ & 241 & 57 & & & & \\
\hline $1958-.59$ & 1525 & 2 & & & & \\
\hline \multicolumn{7}{|l|}{$1959-60$} \\
\hline $1960-61$ & $2760^{*}$ & & & & & \\
\hline \multicolumn{7}{|l|}{$1961-62$} \\
\hline \multicolumn{7}{|l|}{$1962-63$} \\
\hline \multicolumn{7}{|l|}{$1963-64$} \\
\hline \multicolumn{7}{|l|}{$1964-65$} \\
\hline $1965-66$ & & 1 & & & & \\
\hline $1966-67$ & 214 & 9 & & & & \\
\hline $1967-68$ & & & 128 & 498 & 4 & 3 \\
\hline $1968-69$ & & & 95 & & & \\
\hline $1969-70$ & & & 96 & & 312 & \\
\hline $1970-71$ & & & $529 *$ & & 26 & \\
\hline $1971-72$ & & & 101 & 1 & & 1 \\
\hline $1972-73$ & & & 90 & & & \\
\hline $1973-74$ & & & 185 & & & \\
\hline $1974-75$ & & & 118 & 1 & & \\
\hline $1975-76$ & & & $594 *$ & 42 & & 43 \\
\hline $1976-77$ & & & 149 & 22 & & \\
\hline $1977-78$ & & & 149 & 1 & & \\
\hline $1978-79$ & & & $95^{*}$ & & & \\
\hline $1979-80$ & & & 129 & 10 & & \\
\hline $1980-81$ & & & 119 & & & \\
\hline $1981-82$ & & & 73 & & 1 & \\
\hline \multicolumn{7}{|l|}{$1982-83$} \\
\hline $1983-84$ & & & 116 & & & \\
\hline $1984-85$ & & & 158 & 8 & & \\
\hline $1985-86$ & & & 132 & & 26 & \\
\hline Total & 7319 & 810 & 3056 & 583 & 369 & 47 \\
\hline \multicolumn{7}{|l|}{ Recoveries to } \\
\hline 30 June 1986 & & & 73 & 5 & 5 & 1 \\
\hline$\%$ & & & 2.39 & 0.86 & 1.36 & 2.13 \\
\hline
\end{tabular}

* Seasons in which all chicks in the cohort were banded.

northern giant petrels and 369 chicks and 47 adult southern giant petrels were banded on Macquarie Island (table 1).

Three complete cohorts have been banded since 1 JuIy 1967 (1970-7I, 1975-76 and 1978-79) but in 1982-83 no banding was undertaken.
At Macquarie Island, northern giant petrels lay from late September to mid-October; eggs hatch at the end of November and the chicks fledge in mid-March. Chicks were banded on the nest between late December and February, in an area from Handspike Point to Aurora Point (fig. 1), 


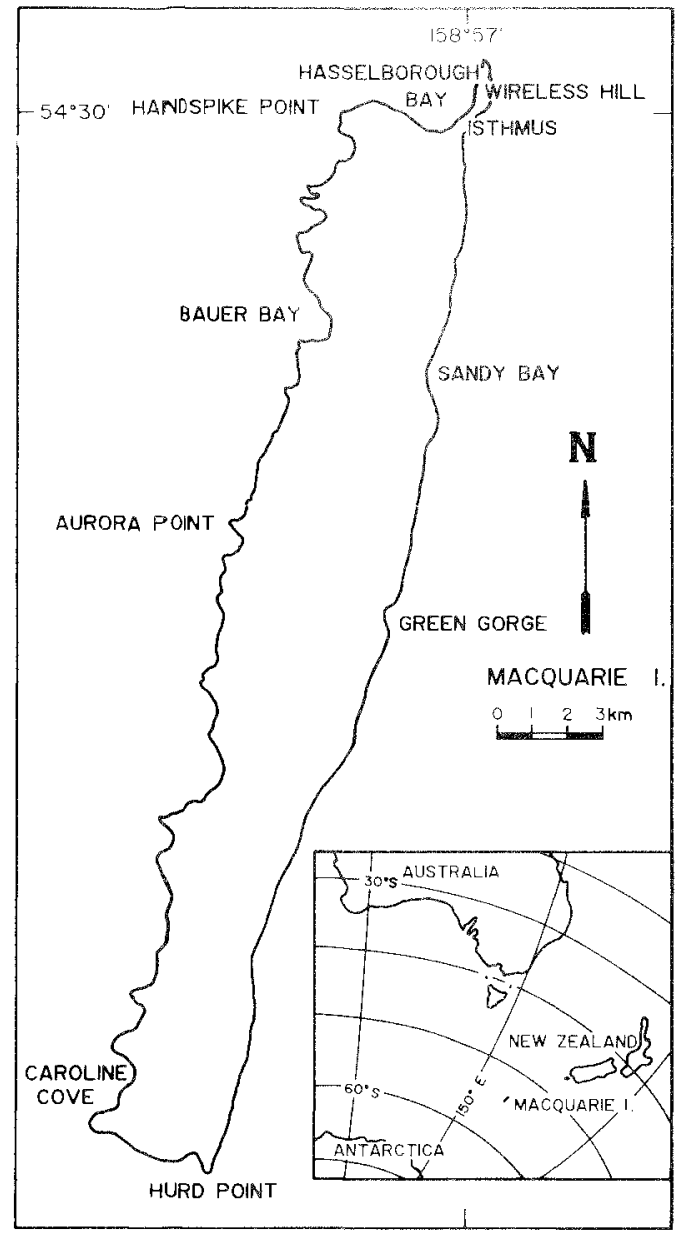

FIG. I - Locality map of Macquarie Island. Banding of chicks and searches for previouslyhanded adults are centred on the area between Handspike Point and Aurora Point.

concurrent with searches for banded adults. Adults were banded on the nest during the breeding season but, in some years, adults have also been banded during the winter months.

The breeding timetable for southern giant petrels is generally four to six weeks later than for northern; laying takes place in November, eggs hatch in mid-January and chicks fledge in May (Johnstone 1971, Warham 1962, Hunter 1984a, b). Chicks were banded on the nest in February and March in the same areas as northern giant petrels.

\section{RESULPS}

Breeding Recoveries of Northern Giant Petrels

A total of 63 aduits (approximately $2.06 \%$ of those banded as chicks) has been recovered as known-age breeding birds. Two of these birds were found breeding in their sixth year. The oldest birds $(n=2)$ were in their 1 sth year (fig. $2 A$ ).

Minimum age of breeding (six years) was used to calculate the distribution of minimum ages

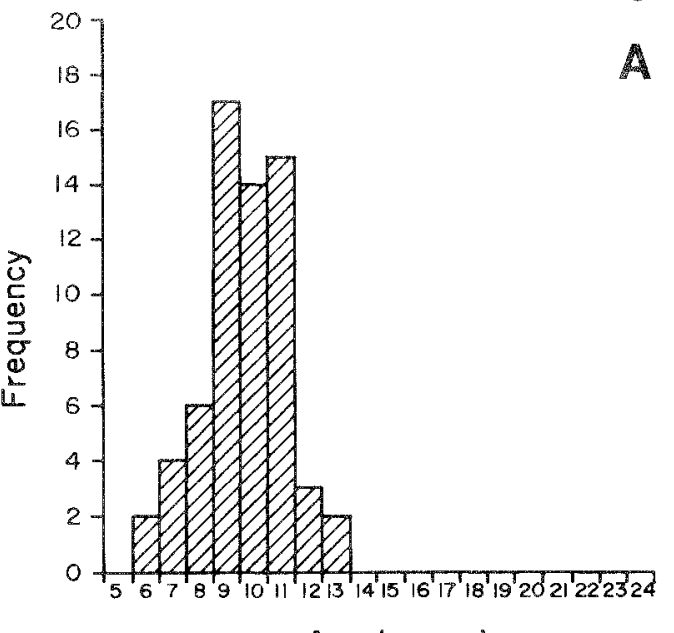

Age (years)

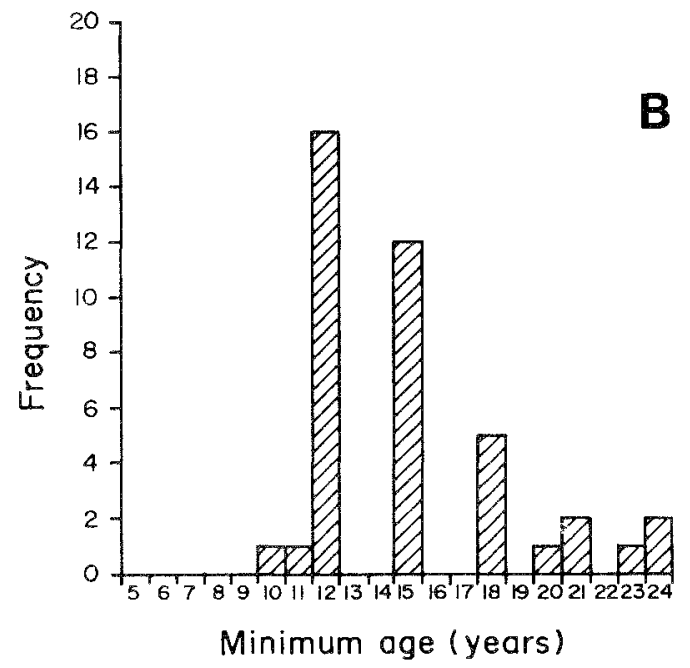

FIG. 2 -- (A) Ages of breeding, known-age northern giant petrels at Macquarie Island, banded as chicks. (B) Minimum ages of breeding northern giant petrels at Macquarie Island, banded as "adult". 

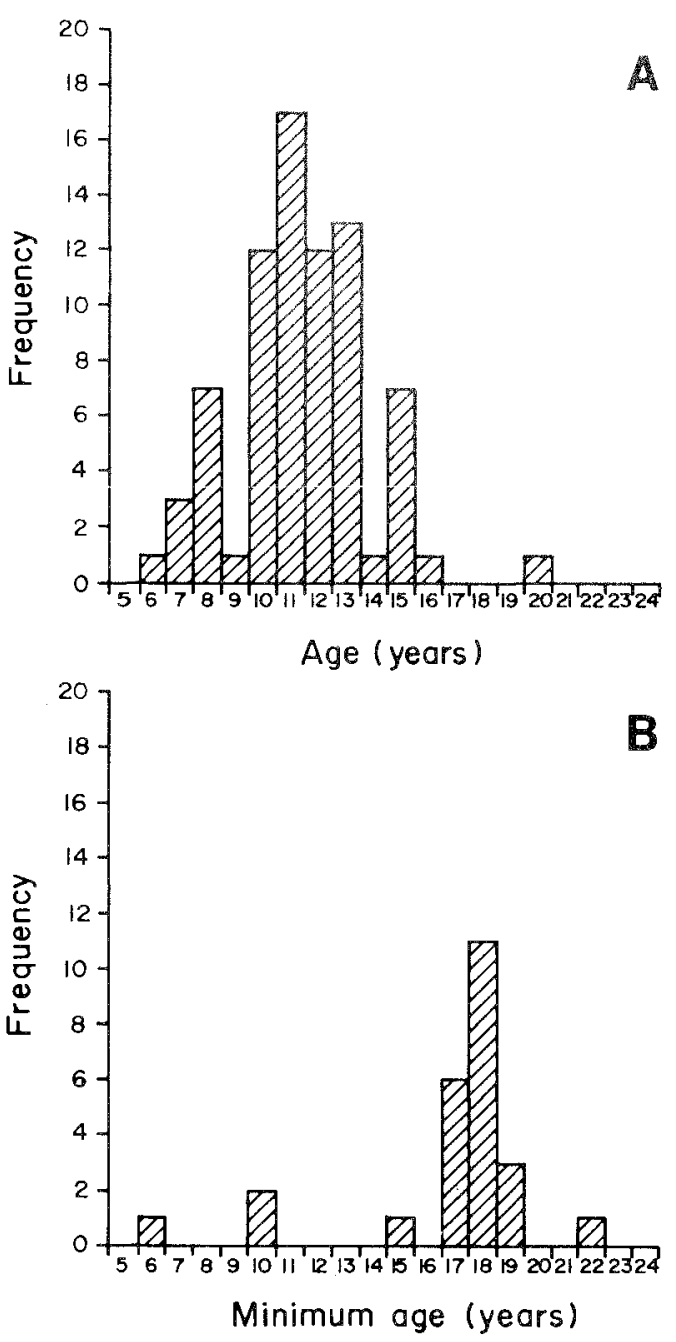

FIG. 3 - (A) Ages of breeding, known-age southern giant petrels at Macquarie lsland, banded as chicks. (B) Minimum ages of breeding southern giant petrels at Macquarie Island, banded as "adult".

of birds banded as "adults" and recovered breeding in subsequent seasons (fig. 2B). Birds banded as breeding adults (October to February) were estimated to be aged " $6+$ " ( 6 years or older $)$ and adults banded during the autumn and winter months to be " $3+$ ", based on plumage. The oldest known northern giant petrel breeding recovery to date was aged $24+$, at least 11 years older than any known-age breeding recovery at Macquarie Island (figs $2 \mathrm{~A} \& \mathrm{~B}$ ).

\section{Breeding Recoveries of Southern Giant Petrels}

A total of 76 adults (approximately $20.6 \%$ of those banded as chicks) has been recovered as breeding birds of known-age. As with the northern giant petrels, the age of first breeding was six years. The oldest known-age breeding recovery was a bird aged 20 years, some seven years older than for the northern giant petrels (fig. $3 \mathrm{~A}$ ).

Using the same ageing protocols as above, the resultant distribution of the ages of 25 breeding adults banded as "adult" is given in figure $3 \mathrm{~B}$. The oldest known breeding recovery of a southern giant petrel from such birds was aged $22+$, at least two years older than any known-age breeding recovery at Macquarie Island.

\section{Distant Recovery Rates}

The recovery locations of all northern and southern giant petrels banded at Macquarie Island as adults or chicks between I July 1967 and 30 June 1986 are shown in figures 4 and 5 respectively. Of the 3056 northern giant petrel chicks banded in this period, there have been 73 recoveries $(2.39 \%)$ alive or dead away from Macquarie Island ("distant" recoveries). There have been five distant recoveries $(0.86 \%)$ from the 583 adults banded.

Five of the 369 southern giant petrel chicks banded in the same period have also been recovered away from Macquarie Island and only one of the 47 adults banded has been recovered. These recovery rates are $1.36 \%$ and $2.13 \%$ respectively; they are similar to those reported by Sladen et al. (1968) and Hunter (1984b).

\section{Age Structure of Distant Recoveries}

One of the 73 distant recoveries of northern giant petrel chicks, which was made at the beginning of February, is considered too early (date of recovery is pre-fledging) and will be ignored in the analyses. Of the remaining 72 recoveries, $42(58 \%)$ were reported in the 12 months following fledging. A further $14(20 \%)$ were reported in the second year and $3(4 \%)$ in the third, resulting in $82 \%$ of recoveries reported within the first three years after fledging. There were also three recoveries of nineyear-old birds banded as chicks (fig. 6A).

The distribution of recoveries in the first year after fledging $(n=42)$ is presented in figure $6 \mathrm{~B}$. The distribution does not differ significantly from the monthly mean of $3.5\left(\chi^{2}=19.2,11\right.$ d.f., $0.10>p>$ $0.05, \mathrm{NS})$. 
FIG. 4 - Recoveries of northern giant petrels banded at Macquarie Island as chicks ( $n=73$ ) and as adults $(\bullet, n=5)$.

\section{Locality of Distant Recoveries}

The localities of all recoveries for both species banded at Macquarie Island are summarised in table 2. Details of the recoveries of northern giant petrels are given in the paragraphs following. There are insufficient recoveries of southern giant petrels $(\mathrm{n}=6)$ for comparisons.

Examination of the latitudes of recoveries of northern giant petrels banded as chicks shows no recoveries north of the equator (Bourne 1967) nor any south of $50^{\circ} \mathrm{S}$ (fig. 7A). Recoveries between

TABLE 2

\section{Summary of Localities and Approximate Distances where Recoveries of Northern and} Southern Giant Petrels, Banded at Macquarie Island, have been Reported

\begin{tabular}{|c|c|c|c|c|c|}
\hline Area & \multicolumn{2}{|c|}{ Northern giant petrel } & \multicolumn{2}{|c|}{ Southern giant petrel } & $\begin{array}{l}\text { Approximate } \\
\text { distance }(\mathrm{km})\end{array}$ \\
\hline Australia & 28 & 4 & 1 & 1 & $1200 \ldots 4000$ \\
\hline New Zealand & 17 & 1 & 1 & & $1200-2600$ \\
\hline South America & 19 & & 2 & & $10000-12500$ \\
\hline Southern Africa & 8 & & & & $9000-11000$ \\
\hline Pacific & 1 & & 1 & & $6300-7700$ \\
\hline Totals & 73 & 5 & 5 & 1 & \\
\hline
\end{tabular}




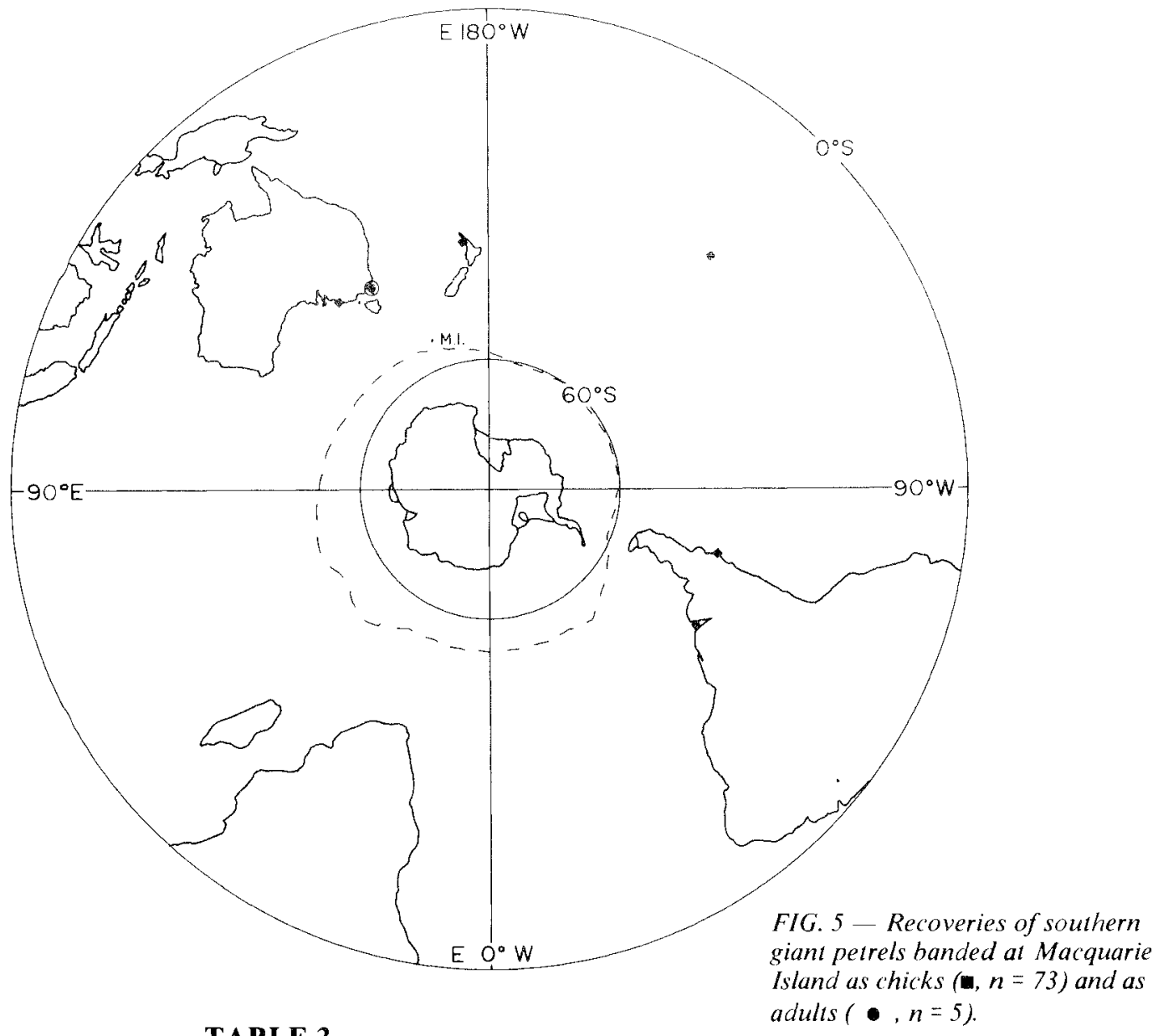

TABLE 3

Frequencies of Recoveries of

Northern Giant Petrels Banded as Chicks

\section{at Macquarie Island}

Latitude

Range

\begin{tabular}{ccc}
\multicolumn{3}{c}{ Frequency } \\
\hline Year 1 & Other & Total \\
$n=41$ & $n=30$ & $n=71^{*}$
\end{tabular}

\begin{tabular}{lrrr}
\hline $00^{\circ} 00^{\prime} \mathrm{S}-04^{\circ} 59^{\prime} \mathrm{S}$ & 1 & 0 & 1 \\
$05^{\circ} 00^{\prime} \mathrm{S}-09^{\circ} 59^{\prime} \mathrm{S}$ & 0 & 0 & 0 \\
$10^{\circ} 00^{\prime} \mathrm{S}-14^{\circ} 59^{\prime} \mathrm{S}$ & 0 & 0 & 0 \\
$15^{\circ} 00^{\prime} \mathrm{S}-19^{\circ} 59^{\prime} \mathrm{S}$ & 1 & 0 & 1 \\
$20^{\circ} 00^{\prime} \mathrm{S}-24^{\circ} 59^{\prime} \mathrm{S}$ & 2 & 1 & 3 \\
$25^{\circ} 00^{\prime} \mathrm{S}-29^{\circ} 59^{\prime} \mathrm{S}$ & 5 & 3 & 8 \\
$30^{\circ} 00^{\prime} \mathrm{S}-34^{\circ} 59^{\prime} \mathrm{S}$ & 16 & 5 & 21 \\
$35^{\circ} 00^{\prime} \mathrm{S}-39^{\circ} 59^{\prime} \mathrm{S}$ & 10 & 14 & 24 \\
$40^{\circ} 00^{\prime} \mathrm{S}-44^{\circ} 59^{\prime} \mathrm{S}$ & 5 & 6 & 11 \\
$45^{\circ} 00^{\prime} \mathrm{S}-49^{\circ} 59^{\prime} \mathrm{S}$ & 1 & 1 & 2 \\
\hline
\end{tabular}

* Two recoveries did not report latitude (see table 2
TABLE 4

Median Month of Recoveries of Northern Giant Petrels Banded as Chicks and Recovered in First Twelve Months after Fledging $(n=42)$

\begin{tabular}{lccl} 
Area & n & $\%$ & $\begin{array}{c}\text { Median } \\
\text { month }\end{array}$ \\
\hline New Zealand & 9 & 21 & March \\
South America & 11 & 26 & May \\
Southern Africa & 4 & 10 & June \\
Australia & 18 & 43 & July \\
\hline
\end{tabular}



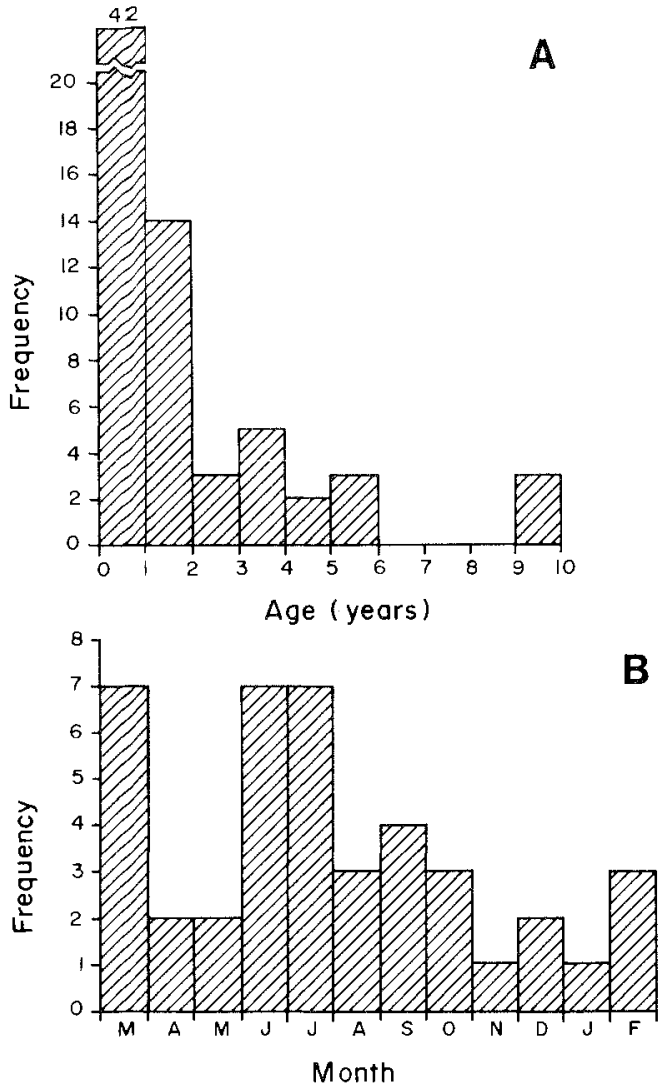

FIG. 6 - (A) Distribution of ages of distant recoveries of northern giant petrels banded at Macquarie Island, $n=72$. (B) Distribution of recoveries within the first year after fledging of northern giant petrels banded at Macquarie Island. $n=42$.

$30^{\circ} \mathrm{S}$ and $40^{\circ} \mathrm{S}$ represent $63 \%$ of both the first year recoveries ( $n=42$ for first 12 months following fledging) and all recoveries $(n=72)$. Recoveries between $25^{\circ} \mathrm{S}$ and $45^{\circ} \mathrm{S}$ account for $88 \%$ of first year recoveries and $90 \%$ of all recoveries (table 3 ).

Similarly, an examination of the longitudes of recoveries (fig. 7B) shows that $62 \%$ of recoveries in the first year following fledging are between $90^{\circ} \mathrm{E}$ and $180^{\circ} \mathrm{E}$ (Australia and New Zealand). A further $26 \%$ are reported from South American longitudes and $11 \%$ from South Africa.

There was an eastward progression of recoveries of northern giant petrel chicks in the first
12 months following fledging (table 4). The median months of recoveries were March in New Zealand, May in South America, June in southern Africa and July in Australia.

\section{Foreign-banded Birds Recovered at Macquarie Island}

Details of four giant petrels banded at other localities and recovered at Macquarie Island are presented in table 5 . The specific identity is known for three of the recoveries, the other is probably a southern giant petrel.
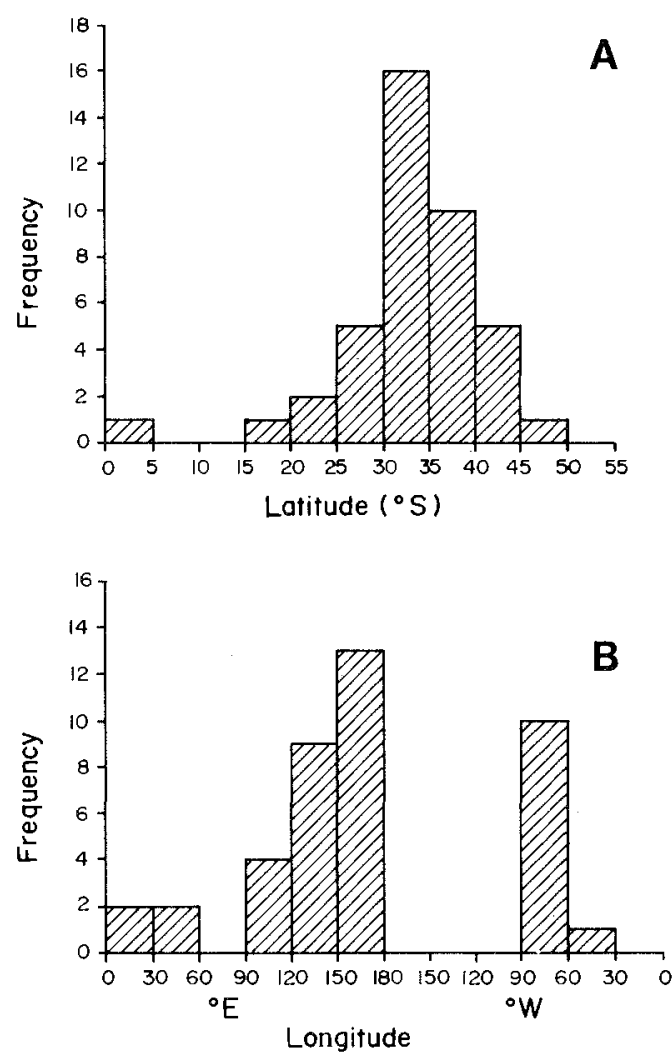

FIG. 7 - (A) Distribution of latitudes of distant recoveries of northern giant petrels banded at Macquarie Island, $n=4 I$. (B) Distribution of longitudes of distant recoveries within the first year after fledging of northern giant petrels banded at Macquarie Island, $n=41$. 
TABLE 5

\section{Foreign-Banded Giant Petrels Recovered at Macquarie Island}

\begin{tabular}{|c|c|c|c|c|}
\hline Species & Band No. & Banding Data & Recovery Date & Status \\
\hline M. halli & 14020656 & $\begin{array}{l}18 \text { Jul } 1970 \\
\text { Malabar, NSW, Aust. } \\
\text { Age: "free-flying" } \\
(1+)\end{array}$ & $\begin{array}{l}11 \text { Sep } 1981 \\
\text { Age: } 12^{+}\end{array}$ & $\begin{array}{l}\text { Breeding, } \\
\text { on egg }\end{array}$ \\
\hline M. halli & $0-2728$ & $\begin{array}{l}18 \text { Aug } 1966 \\
\text { Campbell Is., NZ. } \\
\text { Age: breeding adult } \\
\left(6^{+}\right)\end{array}$ & $\begin{array}{l}5 \text { Feb } 1976 \\
\text { Age: } 15+\end{array}$ & Dead \\
\hline \multirow[t]{2}{*}{ M. giganteus } & $9-52005$ & $\begin{array}{l}22 \text { Feb } 1984 \\
\text { Marion Island } \\
\text { Age: nestling }\end{array}$ & $\begin{array}{l}20 \text { May } 1984 \\
\text { Age: } 1\end{array}$ & Dead \\
\hline & 10156 & $\begin{array}{l}\text { (Argentinian Band) } \\
\text { Location and age } \\
\text { unknown }\end{array}$ & $20 \mathrm{~J} \operatorname{an} 1986$ & Dead \\
\hline
\end{tabular}

\section{DISCUSSION}

\section{Age at First Breeding and Longevity}

The youngest known-age northern and southern giant petrels recovered breeding were six years old. These results agree with those reported by Hunter (1984a) at South Georgia. Conroy (1972) reported the age at first breeding of southern giant petrels at Signy Island to be five years, with evidence of sexual differences in age at first breeding, males breeding earlier than females. Similar evidence was presented by Mougin (1968).

Recoveries of breeding northern and southern giant petrels originally banded as "adults" indicate that individuals can live to at least 24 and 22 years respectively. These data suggest that individuals can contribute to the breeding population for at least 18 and 16 years.

Croxall (1981) reported mean life expectancies for breeding birds of 24.5 years for southern giant petrels but only 9.5 years for northern giant petrels. The results obtained in this study would indicate mean life expectancies for northern giant petrels to approach those of the southern giant petrel.

More detailed analyses of the age structure of the breeding populations are not possible, since search and banding efforts were not consistent from year to year.

\section{Distant Recoveries}

The distribution of distant recoveries for both species reported here (and in previous accounts) is strongly associated with the distribution of land masses in the Southern Hemisphere and the concomitant distribution of population centres. Such associations may introduce biases to recovery rates and the geographic distribution of reports of recoveries.

The eastward circum-polar progression of recoveries reported here is similar to those previously documented and can be attributed to fledglings using the predominant westerly winds (Downes et al. 1954, Tickell \& Scotland 1961, Sladen et al. 1968, Hunter 1984b).

Hunter (1984b) reported a peak of southern giant petrel recoveries in July in the first year after fledging, but no such peak for northern giant petrels. The distribution of recoveries reported here (fig. 6B) shows small peaks in March, June and July, but these are not statistically significant.

High recovery rates in Australian waters reported in this study and others (Araya 1973, Hunter 1984b) suggest these waters may serve as wintering areas for both species. Wheeler (1973) and Jones (1973) reported the presence of large numbers of giant petrels in Victorian and New South Wales waters during winter months. Blakers et al. (1984) documented higher reporting rates 
during winter months for both species in southern and southeastern Australian waters.

Serventy et al. (1971) and Johnstone (1974) suggested from observations at sea, that the Antarctic Convergence acted as an ecological barrier between the two species of giant petrels during the summer mo nths but not in winter. The lack of any recoveries of northern giant petrels south of $50^{\circ} \mathrm{S}$ in this study supports such a conclusion. The few recoveries of southern giant petrels were also reported from north of an Antarctic Convergence; however, all but one were from winter months.

Only $4 \%(n=3)$ of distant recoveries of northern giant petrels banded as chicks on Macquarie Island were made as birds of breeding age, i.e. birds six years of age or older. Of the 26 known-age recoveries of southern and northern giant petrels reported by Jones (1973), only one $(3.9 \%)$ was a bird of breeding age (eight years old), all others were less than one year old. These data agree with published accounts (Tickell \& Scotland 1961, Bourne \& Warham 1966) that, with increasing age, birds are distributed close to the breeding areas. Warham (1962) reported adult giant petrels present at $M$ acquarie Island throughout the winter months and Hunter (1984b) suggested that once birds had at tained breeding age at South Georgia, they were unlikely to leave the island.

\section{Foreign-banded Recoveries at Macquarie Island}

Hunter (1984b) demonstrated that changes between natal and breeding sites were rare. The northern giant petrel, banded at Malabar, N.S.W., as a free-flyer and recovered breeding at Macquarie Island, had presumably also fledged at Macquarie Island. However, the other northern giant petrel, originally banded as a breeding adult at Campbell Island some $740 \mathrm{~km}$ to the northeast, may have changed its breeding location. One southern giant petrel (130 04218) banded at Macquarie Island in 1955 as a breeding adult was subsequently recovered breeding at Cape Crozier, Ross Island, Antarctica (E.J. Woehler \& G.W. Johnstone, unpublished data). It would appear that changes in breeding locations occurs in both species.

\section{ACKNOWLEDGEMENTS}

We wish to thank Mr H.R. Burton and Drs K.W. Lowe and P.G. Quilty for their help and encouragement. Mr M.A. Hindell provided advice and valuable discussions. The assistance of the Australian Bird and Bat Banding Schemes is gratefully acknowledged. Finally, we wish to thank the organisers of the Macquarie Island Symposium for the opportunity to present the results of this study.

\section{REFERENCES}

ARAYA, B., 1973: Recaptura de petreles gigantes anillados en Isla Nelson, Antarctica Chilena. Revta Biol. Mar., 15:111 114.

BLAKERS, M., DAVIES, S.J.J.F. \& REILLY, P.N., 1984: THE ATLAS OF AUSTRALIAN $B I R D S$. Melbourne University Press, Melbourne.

BOURNE, W.R.P., 1967: Long-distance vagrancy in the petrels. Ibis, 109:141 167 .

BOURNE, W.R.P.\& WARHAM, J., 1966: Geographical variation in the giant petrels of the genus Macronectes. Ardea, 54: 4567.

CONROY, J.W.H., 1972: Ecological aspects of the biology of the giant petrel Macronectes giganteus (Gmelin) in the Maritime Antarctic. Br. Antarc. Surv. Sci. Rep., No. 75: 1-74.

CROXALL, J.P., 1981: Aspects of the population demography of Antarctic and Subantarctic seabirds. C.N.F.R.A., 51: $479-488$.

DOWNES, M.C., GWYNN, A.M. \& HOWARD, P.F., 1954: Banding of giant petrels at Heard and Macquarie Islands. Emu, 54: 257-262.

HOWARD, P.F., 1956: Banding of giant petrels at Heard and Macquarie Islands II. Emu, 56: $401 \div 404$

HUNTER, S., 1984a: Breeding biology and population dynamics of giant petrels Macronectes at South Georgia (Aves:Procellariiformes). J. Zool. (Lond.), 203: 441460.

HUNTER, S., 1984b: Movements of giant petrels Macronectes spp. ringed at South Georgia. Ring. and Migr., 5: $105-112$.

HUNTER, S., 1985: The role of giant petrels in the Southern Ocean ecosystem. In Siegfried, W.R., Condy, P.R. \& Laws, R.M. (Eds): ANTARCTIC NUTRIENT CYCLES AND FOOD WEBS. Springer-Verlag, Berlin: 534-542.

INGHAM, S.E., 1959: Banding of giant petrels by the Australian National Antarctic Research Expeditions, 1955-1958. Emu, 59: 189-200.

JOHNSTONE, G.W., 1971: Bird in the hand -- Giant petrels. Aust. Bird Bander, 9: 86-87. 
JOHNSTONE, G.W., 1974: Field characters and behaviour at sea of giant petrels in relation to their oceanic distribution. Emu, 74: 209218.

JOHNSTONE, G.W., 1977: Comparative feeding ecology of the giant petrels Macronectes giganteus (Gmelin) and $M$. halli (Matthews). In Llano, G.A. (Ed.): ADAPTATIONS WITHIN ANT$A R C T / C$ ECOSYSTEMS. Smithsonian Institute, Washington, D.C.: 647.668.

JONES, B., 1973: Studies of giant petrels at Malabar, New South Wales. Aust. Bird Bander, 11:47.50.

MOUGIN, J.L., 1968: Etude ecologique de quatre especes de petrels antarctiques. Oiseau, 38: I 52.

SER VENTY, D.L., SERVENTY, V. \& WARHAM, J. 1971: THE HANDBOOK OF AUSTRALIAN SEABIRDS. A.H.\& A.W. Reed.
SLADEN, W.J WOOD R.C \& MONAGHAN, E.P., 1968: The U.S.A.R.P. bird banding program, 1958 65. In Austin, O.L. Jnr (Ed.): ANTARCTIC BIRD STUDIES. Antarctic Research Series, Vol.12. American Geophysical Union, Washington, D.C.: 213228 .

TICKELL, W.L.N. \& SCOTIAND, C.D., 1961: Recoveries of ringed giant petrels Macronectes giganteus. Ibis, 103a: 260266

WARHAM, J., 1962: The biology of the giant petrel Macronectes giganteus. Auk, 79: 139160.

WHEELER, J.R., 1973: Giant petrel banding near Barwon Heads, Victoria. Aust. Bird Bander, ll: 11.

(accepted 14 October 1987) 